\title{
PRODUCTIVE WAYS OF FORMATION OF CHEMICAL AND BIOLOGICAL TERMS (IN ENGLISH, RUSSIAN AND TATAR LANGUAGES)
}

Leila Aivazovna Nurgalieva Kazan Federal University, Kazan, Russia.

Lucia Munirovna Ibatulina Kazan Federal University, Kazan, Russia.

Venera Nafikovna Khisamova Kazan Federal University, Kazan, Russia.

Gitación sugerida:

Nurgalieva, L.A., Ibatulina, L.M. y Khisamova, V.N. (2019). Productive ways of formation of chemical and biological terms (in English, Russian and Tatar languages). 3C TIC. Cuadernos de desarrollo aplicados a las TIC. Edición Especial, Octubre 2019, 58-71. doi: https://doi.org/10.17993/3ctic.2019.83-2.58-71

\section{Suggested citation:}

Nurgalieva, L.A., Ibatulina, L.M. \& Khisamova, V.N. (2019). Productive ways of formation of chemical and biological terms (in English, Russian and Tatar languages). 3C TIC. Cuadernos de desarrollo aplicados a las TIC. Special Issue, October 2019, 58-71. doi: https://doi.org/10.17993/3ctic.2019.83-2.58-71 


\section{ABSTRACT}

Terminology is one of the most important problems of modern linguistics. The study of terminological systems of typologically different languages is of great scientific interest. The article deals with the productive methods of word formation in English, Russian and Tatar chemical and biological terminology on the example of suffixation, compounding, conversion and abbreviation. The purpose of the present study is to identify the features of these methods in the chemical and biological term systems of genetically unrelated and typologically diverse languages. The general models of word formation typical for the languages studied in this article are considered and presented.

\section{KEYWORDS}

Linguistics, Language, Words, Chemical terminology, Biological terminology, Word formation, English, Russian, Tatar. 


\section{INTRODUCTION}

In the modern world scientific knowledge plays an important role in the development of society. Due to the entry into global scientific and educational sphere, it is necessary to know features of academic style in English which is international language of scientific communication along with peculiarities of language of science in native language.

The importance of the question is proved by works of many researchers. Khuziahmetov and Valeev (2018) study peculiarities of bilingual learning of English and Tatar languages and pointed out that "it becomes necessary to pay special attention to the problem of the ability of students to effectively participate in the intercultural communication and a productive solution to this issue is the orientation toward bilingual education".

Khisamova, Motygoullina and Moullagaliev (2015), consider "the process of globalization and unification of the modern sciences into a new organized idea of using results of one scientific area in some different researches. For example, in revising the peculiarities of translating Anglo-American fiction into the Tatar language they can refer to the different layers of the linguistics, such as comparative linguistics, typology, translation theory and the real modality".

The research of terminology is among the most important problems of modern linguistics. In this regard studying term systems of typologically diverse languages is of great scientific interest.

Terminological vocabulary as a part of dictionary structure of language has several properties. It is the most developing part of dictionary structure in comparison with its other parts.

Study of terminology assumes not only consideration of terms and their functions, but also the analysis of sources and ways of their production. It is on the material of terminological vocabulary operation of laws of language, mainly of wordformation, is most shown (Kozhanova et al., 2017; Kheirabadi \& Mirzaei, 2019; Barati et al., 2018; Kashisaz \& Mobaraki, 2018). 
The science which deals with studying of terminology is called term study. The contribution to development of this discipline was made by scientists Vinogradov, Lott, Vinokur, Reformatsky, Budagov, Akhmanova, Piotrovsky and many others (Reformatskii, 1967).

Studying of peculiarities of word formation in language of chemistry and biology represents undoubted interest as the correct understanding of regularities of modern terminological word formation helps to carry out the process of term formation (Abilgaziyeva et al, 2018; Eslami \& Ahmadi, 2019; Jabbari et al., 2019; Nakhaee \& Nasrabadi, 2019).

Now word formation in terminology is a source of many linguistic researches devoted to various term systems on the basis of different languages.

\section{METHODS}

We understand as ways of word formation "receptions, methods of formation of new words from any material units of language by creation between them the word-formation relations" (Zakiev et al., 1995).

In this article we consider the most productive ways of formation of chemical and biological terms in the English, Russian and Tatar languages. Dictionaries of chemistry and biology in given languages are used in this article. The main method of our research is comparative analysis.

\section{RESULTS AND DISCUSSION}

One of the most productive ways to form chemical and biological terms in the English, Russian, and Tatar languages is affixation.

There are several terms formed by suffixation, that is, adding a suffix to the stem that is a morpheme which follows the root. Unlike prefixation, which affects the lexical-grammatical component of a word, suffixation, as a rule, allows to create words that relate to another part of speech or to another class of words. 
Let's consider a group of suffixes which new terms or words are formed from and which fulfills the role of a noun. In English, this group includes the suffixes -er, -or, -ent and -ant, which are used to form nouns denoting a person or mechanism with a specific action: to activate - activator, to absorb - absorbent, to carry - carrier. The same group includes the suffixes -ion, -ation, -ment, -ure, -age, -ence, - ance, -ing, with the help of which new terms are formed from verbs that express some concepts of nouns: exposure, oxidation, reaction.

In the formation of chemical and biological terms that perform the role of a noun in the Tatar language, the most productive suffixes are: -льљ//-лек, -гъци/геи (-кьги/-кеи), -чьљ/-че, -льљ/-ле, -чан/-чән, -ма/-мә, -ла/-лә, -лаштьгр/-ләштер. The suffix $-л ь љ /-л е к$ is a word-forming formant in many Turkic languages. With the help of this suffix in Tatar chemical and biological terms from nouns are formed, denoting the presence of quality, indicated by the manufacturing basis:

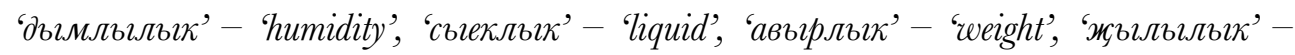
'heat', 'зурльик' - 'quantity' etc.

The suffix -льıк, can join the borrowed chemical or biological terms and form such words as: 'активлью' - 'activity' 'валентлью' 'valence', 'изоморфльюћ' 'isomorphism'.

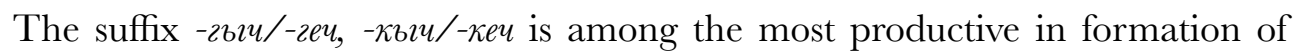
chemical and biological terms. It forms names of substances or medicines, expresses value of adaptation, installation or the tool for the action. For example: 'алмаштьгргъи' - 'substitute', 'беркеткеи' - 'fiхеr', 'йоткьич' - 'absorbent', 'оксидлаштьиргъи' - 'oxidant', etc.

In Russian a productive suffix for term formation is formed from stems of the borrowed nouns and meant branches of science: химия, биология, биохимия; chemical and biological processes and phenomena: автогамия, адаптаиия, аллотропия, дисперсия, диффузия, гомология, мезомерия. Тhе suffix - op is also productive. Nouns with this suffix are names of technical devices, apparatus: аспиратор, вентилятор, дистиллятор, конвертор, реактор and names of substances, materials which carry out some actions: активатор, анализатор, ингбитор, катализатор, репрессор, регулятор. 
The suffix -ени- means action as the phenomenon leading to any result: беление, брожение, бромирование, вальиевание, водопоглощение, галогенирование, давление. The suffix -ость in the terms formed from stems of descriptive adjectives means properties: аффинность, вирулентность, газоустойчивость, матовость, мелкопористость, мьилкость, неоднородность, основность, пластичность, продуктивность.

In works of many scientists compounding is mentioned as one of the most important means of language. In the examined languages this way of a term formation is one of old ways of creation of words which does not lose its productivity. The compounding is an important source of language vocabulary supplement. It is the process of composition of two or several stems in one compound word.

There is certain relationship between components of a compounding in the studied languages. It is coordinating or subordinating relationship. At the coordinating relations all components of a compound word are equal in the structural and semantic plan and make two structural-semantic centers. For example:

protein-ligand, enzyme-substrate;

винил-кушьллма, атом-төш, балчълк-бетон;

винил-соединение, глинобетон.

At the subordinating relations one component of the word is dominant and is the structural and grammatical center which means that it defines belonging to a certain lexical and grammatical category and a part of speech.

The subordinating relation is a main type of word connection in language. There are the following types of compounding with the subordinating relation of components: the attributive relation of components, the objective relation of components and the adverbial relation of components. 
In chemical and biological terminology of the studied languages compound words with the attributive relation of components prevail. The noun acts as the second component in them, the noun, an adjective, a pronoun, a numeral or a participle can be the first components.

Saidasheva (2006) pointed out that there are models of compounding common for English and Tatar. We found out that these models are also presented in Russian language.

They are:

1. Noun $+\operatorname{noun}(\mathrm{N}+\mathrm{N})$ :

unit cell, radioactivity, wavelength, oxidation-reduction, activation energy';

атом төше, балчвюк сөзгеи, аш тозьг, вак бөртеклелек, вак тишеклеклек, энже бөртеге;

аквасоединене, альфа-излучатель, газометр, гелеобразование, еж-рьба, жабаръъба.

2. Adjective + noun $(\mathrm{A}+\mathrm{N})$ :

acid-base, amino-terminal, free-energy, supercooling;

калай кисәге, тимер бактерияларе, түба калае;

железобетон.

3. Pronoun + noun $(\operatorname{Pr}+\mathrm{N})$ :

nonelectrolyte;

уздифбузия, узагач;

неэлектролит, самодиффузия.

4. Numeral + noun $(\mathrm{Num}+\mathrm{N})$ :

first-order reactions, two-component;

беркету, беркислотальи, икеузәкле бдйләнеш, икенигезле, өчнигезле кислоталар;

одноклеточнъие, двукисточник, двукрвилатка, триостренник, триперстовъее. 
5. Participle $+\operatorname{noun}(\mathrm{P}+\mathrm{N})$ :

boiling-point, branched-chain;

иинкланган тимер, чәчелүчәнек.

Along with a suffixation and a compounding, conversion in the studied languages is a highly productive way of a term formation. Conversion is the word formation process in which a word of one grammatical form becomes a word of another grammatical form without any changes to spelling or pronunciation. Thus conversion is a lexical and grammatical way of formation of new words. This way of enrichment of terminology is applied in English and Russian, and in Tatar languages.

In Tatar nouns, adjectives, adverbs, postpositions, particles, interjections and conjunctions are formed by means of conversion. The most productive is formation of nouns, adjectives, adverbs and postpositions (Zakiev et al., 1995).

In chemical terminology nouns denoting materials, metals, chemicals and their types become adjectives (Zakieva, 2011):

$$
\begin{gathered}
\text { Алтьлн - алтьгн 'gold-golden', көмеш-көмеш 'silver-silvery', энже - энже } \\
\text { 'pearl-pearly'. }
\end{gathered}
$$

As for English, the most productive is the model noun - verb. It is the only productive way of formation of verbs from nouns:

$$
\begin{aligned}
& \text { fuel, } n,-f u e l, v \\
& \text { water } n-\text { water, v } \\
& \text { heat, } n-\text { heat, v. }
\end{aligned}
$$

In Russian there are three types of conversion: substantivation, adjectivization and adverbialization. Substantivation is transition of a word from the category of adjectives in the category of nouns. Adjectivization is transition of words 
to the category of adjectives. As a rule, verbs and verbal forms (participles) form conversion base for formation of this sort of adjectives: дрессированныги, опубликованньй, закрьгтьй еtс.

Substantivation is characteristic feature for the language of biology. Such adjectives as альбатросовъге, баклановъе, веерокрьльие еtc. became nouns.

There are many abbreviations in language of chemistry and biology in English, Russian and Tatar. With the development of science many new terms in the form of compound words and phrases which come to terminological contraction appear.

There are various types of structural contractions. For the English, Russian and Tatar languages the general are graphic and lexical types.

Graphic contraction is use of symbols, reduction of words and phrases in a written language, at the same time in oral speech full forms are used. Symbols and signs belong to examples of graphic abbreviation in chemistry and biology: $C$ - Celsius degree of teтрегаture, температура, Цельсий градусьида, температура по Цельсию; е. g. - for eхатрle; h.б.и. - һәм башка шушьиндъ; $d$-density, плотность, тьиъъзльи; $K$ teтperature of Kelvin, температура по Кельвину, температура, Кельвинда.

Lexical abbreviations are formed by means of process of simultaneous contraction and compounding. This way includes initial abbreviation. It is a way of word formation by addition of the reduced initial letters or sounds of a phrase. This contracted form is used also at pronunciation: ACFOR scale (Abundant Common Frequent Occasional Rare), ACTH (Adrenocorticotropic hormone), DNA (deoxyribonucleic acid), KE (kinetic energy), RNA (ribonucleic acid), STP (standard temperature and pressure), EFG (Epidermal Growth Factor); ATФ (аденозинтрифосфат), БАК (белок-активатор), ЗПА (зона поляризуюощей активности); РНК (рибонуклеин кислотась), ДНК (дезоксирибонуклеин кислотасъг), ХКС (хальгкара классификация системасы). 


\section{SUMMARY}

Suffixation is the most productive way of term formation in all three languages. The suffixes of noun formation with the same meaning occur in all of them. In compounding many complex chemical and biological terms is formed by addition of stems with the attributive relation of components where the first component is attribute of the second. This feature is characteristic for the English and Russian languages, and for Tatar. As for conversion which is common for all three languages in English first place is taken by the noun - verb model, in Russian noun - noun, and in Tatar highly productive model is noun - adjective. Abbreviation along with compounding and conversion represents a productive way of word formation. For the languages investigated in this article the general are such types of contractions as graphic and lexical.

\section{CONCLUSIONS}

We studied suffixation, compounding, conversion and abbreviation as the most productive ways of a term formation and identified the features of these methods of word formation in the chemical and biological term systems of three genetically unrelated and typologically diverse languages. Suffixation is the most productive way of term formation in them. The general models of word composition typical for the languages studied in this article are considered and presented. There are differences in models that are productive for each language in case of conversion. In the presentation of the abbreviation we showed models which are common for the English, Russian and Tatar languages.

\section{ACKNOWLEDGEMENTS}

The work is performed according to the Russian Government Program of Competitive Growth of Kazan Federal University. 


\section{REFERENCES}

Abilgaziyeva, Z. K., Janzakova, S. I., \& Nurgaliyeva, S. A. (2018). Speech activity among the junior students in teaching foreign languages. Opción, 34(85-2), 627-652.

Barati, M., Bahremand Joo, S., \& Mohammadi Aria, A. (2018). The effect of metacognitive beliefs and self-regulation strategies on students' academic motivation. UCT Journal of Social Sciences and Humanities Research, 6(1), 1823. Retrieved from http://www.globsci.com/index.php/ytuyk/article/ viewFile/527/516

Eslami, R., \& Ahmadi, S. (2019). Investigating the Role of Educational Media on Secondary School Students' Learning Process Improvement in Jahrom City. Fournal of Humanities Insights, 03(01), 13-16. doi: https://doi.org/10.22034/ jhi.2019.80890

Jabbari, E., Charbaghi, Z., \& Dana, A. (2019). Investigating the Effects of Educational and Motivational Education at Different Levels on the Performance and Application of dart throwing. Fournal of Humanities Insights, 03(02), 37-44. doi: https://doi.org/10.22034/jhi.2019.80896

Kashisaz, S., \& Mobaraki, E. (2018). The Effects of Private Education Institutes in Providing Modern Financial Knowledge in Developing Countries. Fournal of Humanities Insights, 02(04), 172-178. doi: https://doi.org/10.22034/ jhi.2018.80887

Kheirabadi, M. A., \& Mirzaei, Z. (2019). Descriptive valuation pattern in education and training system: a mixed study. Fournal of Humanities Insights, 03(01), 7-12. doi: https://doi.org/10.22034/jhi.2019.80889

Khisamova, V., Motygoullina, Z., \& Moullagaliev, N. (2015). Expression of the fiction in the material of «The catcher in the rye» by David Salinger and its translation into the Tatar language. Journal of Language and Literature, 3(6), 140-143. 
Khuziahmetov, A. N., \& Valeev, A. A. (2018). Advantages of bilingual training in national schools. XLinguae, 11(1), 114-125. doi: https://doi.org/10.18355/ XL.2018.11.01.11

Kozhanova, M. B., Svechnikova, N. V., Akhmetzyanova, G. N., Kondrashova, E. N., Maksimova, N. L., \& Zakharova, Z. A. (2017). Psycho-Pedagogical Conditions of Professional Culture Development of a University Professor. International Electronic fournal of Mathematics Education, 12(1), 15-23. Retrieved from https://www.iejme.com/article/psycho-pedagogicalconditions-of-professional-culture-development-of-a-university-professor

Nakhaee, J., \& Nasrabadi, M. A. (2019). Strategies for Research-Centered Education of Architectural Designing by Examining the Research-Centered Activities of the Top Universities. Fournal of Humanities Insights, 3(02), 50-56. doi: https://doi.org/10.22034/jhi.2019.80898

Reformatskii, A. A. (1967). Termin kak chlen leksicheskoi sistemy iazyka [Term as a member of the lexical system of language]. Problemy strukturnoi lingvistiki. Moscow: Nauka.

Saidasheva, E. A. (2006). Slovoobrazovanie v tatarskom i angliiskom iazykakh na primere konversii i slovoslozheniia: Sopostavitel'nyi analiz [Word formation in the Tatar and English languages on the example of conversion and word composition: Comparative analysis].: avtoreferat dis. ... kand. filologicheskikh nauk: Kazan', - 24 s. (In Russian)

Zakiev, M. Z., Ganiev, F. A., \& Salimov, Kh. Kh. (1995). Tatarskaia grammatika [Tatar Grammar]. - T. 1: Vvedenie. Fonetika. Fonologiia. Prosodika. Grafika i orfografiia. Orfoepiia. Osnovnye poniatiia grammatiki. Morfemika. Morfonologiia. Slovoobrazovanie. 583 p.

Zakieva, Z. R. (2011). Sposoby slovoobrazovaniia kak faktor sistemnosti terminologii khimii $\mathrm{v}$ tatarskom iazyke [Methods of word formation as a factor of systematic terminology of chemistry in the Tatar language]. Vestnik ChelGU, 8 . 
Edición Especial Special Issue Octubre 2019 DOI: https://doi.org/10.17993/3ctic.2019.83-2.58-71 